\title{
ICT for post-2015 education: An analysis of access and inclusion in sub-Saharan Africa
}

Tsegay, Samson Maekele $\measuredangle$

Beijing Normal University, China (Samex221@gmail.com)

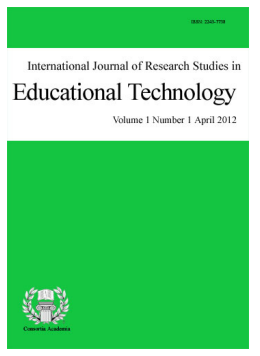

Received: 14 February 2016

Revised: 21 June 2016

Available Online: 1 August 2016

\section{Abstract}

The study focuses on Information and Communication Technology (ICT) for post-2015 education in sub-Saharan Africa, by examining the current conditions and future trends of ICT and its integration in education. Through secondary data and semi-structured interview, it is mainly centered on the question whether Sub-Saharan Africa could ensure "access and inclusion" by 2030. The study indicated that the current low development of ICT interweaved with the socio-economic and political conditions of sub-Saharan Africa could be a challenge to ensure all girls and boys to have access to connected digital devices and relevant and responsive digital learning environment by 2030. However, there is a glimpse of hope that, with the increasing commitment of many countries and technological revolution of the world, few countries might achieve the goal. The study could be used for shaping the policy of developing countries in dealing with the development of ICT and its application in social services with particular emphasis in education.

Keywords: Information and Communication Technology; post-2015 education; sub-Saharan Africa; access; inclusive education 


\section{ICT for post-2015 education: An analysis of access and inclusion in sub-Saharan Africa}

\section{Introduction}

Education is a process of changing the behavior patterns of people. This is using behavior in the broad sense to include thinking and feeling as well as overt action. It is through this personal development that goes towards the national and global awareness of citizens. Educating qualified citizens has been the indispensable task of every nation-state to respond to the new economic and cultural orientation (Marginson, 2010) which has been brought about by socio-economic and political developments. Governments plan their educational system continuously as societies envision possibilities for improving upon present conditions; translate their perception of the gap between present realities and envisioned possibilities into goals; and assign responsibility for achieving these goals in the educational institutions. These policies include integration of Information and Communication Technology (ICT) and all the strategies and means used for its implementation to enable learners to cope with the rapidly changing world. The technological development of the world is not only transforming industries from simple, manual and local to more technological, professional and global levels; but it is simultaneously renovating education with the integration of ICT. ICT encompasses all the technology that facilitates the processing, transfer and exchange of information and communication services (Osterwalder, 2003).

Different global education and education-related goals such as Education for All (EFA) and Millennium Development Goals (MDGs) expired in 2015. Hence, the international community has set new development agenda for post-2015 education for the next 15 years with the aim of eradicating poverty and ensuring sustainable development worldwide based on the principles of access, equity, and quality, in the perspective of lifelong learning for all (Dorsi, 2015). In this new global agenda, nation-states are moving with the principle that ICT could play a crucial part in achieving these goals. Despite their broad and highly contested nature, different researches indicate that ICT could positively influence the distribution and quality of education. With the rise of the Internet, many have seen ICT as a tool to narrow the gap between developing and developed world (Duță \& Martínez-Rivera, 2015; Negroponte, 1998). However, there are studies arguing that various challenges are dragging the development of ICT in many developing countries (Parliamentary Office of Science and Technology, 2006). This indicates that there is ICT disparity within and between countries, and this digital divide is widening the educational gap between those with access to ICT and those without or with less access.

This paper explores the role of ICT in post-2015 education. Through semi-structured interview and secondary data, it particularly analyzes how far all students will get access to ICT to strengthen education and its knowledge dissemination capacity in post-2015 education in sub-Saharan Africa, the region of Africa that lies south of the Sahara Desert. To analyze on the current condition and future trends of ICT to achieve inclusive and equitable quality education by 2030, the study basically focused on two research questions: (1) How is the development of ICT and its integration in education in sub-Saharan Africa, and (2) what are the opportunities and challenges that sub-Saharan Africa could ensure all students to have access to connected digital devices and relevant and responsive digital learning environment by 2030 ?

\subsection{Research Background}

It has been common to see nation-states to organize under regional or global organizations and set similar educational goals such as the MDGs. In 2000, member countries of the United Nations set the target of halving global poverty by 2015; and in order to achieve this, they established eight MDGs and set various indicators to monitor the targets for achieving each goal (UNDP, 2010). Goal two "achieve universal primary education" was aimed to ensure all children everywhere, boys and girls alike, to be able to complete a full course of primary schooling by 2015 . However, the UN (2015) statistics indicate that in 2015, 57 million children of primary 
school age were out of school, down from 100 million in 2000. This means that within fifteen years the world did not meet the goal 'universal primary education', but it covered about half of the goal. The second disturbing thing is that almost all of these out of school children are found in developing countries, and more than half of them live in one continent and specific region, sub-Saharan Africa. It could be argued that this was quite clear from the beginning of the MDGs. This is because setting the same goal and the same timeframe for all countries regardless of their background, problems and economic development could not be realistic, unless they are given comprehensive assistance in its achievement.

In May 2015, the world education leaders and policy makers also met in Incheon, Republic of Korea, and Qingdao, China, at the World Education Forum (WEF) and the International Conference on ICT and Post-2015 Education respectively to discuss on post-2015 education with the goal towards inclusive and equitable quality education and lifelong learning for all by 2030 (UNESCO, 2015b). The researcher had an opportunity to participate in the International Conference on ICT and Post-2015 Education which was held from 23 to 25 May 2015 in Qingdao. The participants reiterated the challenges and prospects of the post-2015 education especially in the integration of ICT in education. Many of the participants also argued that the Qingdao Declaration is not fully considering the situation of developing countries which might lag behind as they did in the MDGs.

This paper tries to critically analyze, from the perspective of sub-Saharan Africa, the Qingdao Declaration on "access and inclusion" which emphasize ensuring all girls and boys to have access to connected digital devices and relevant and responsive digital learning environment by 2030, irrespective of their disabilities, social or economic status, or geographic location.

\subsection{Purpose of the Study}

This study explores the capacity and role of ICT in developing countries for post-2015 education, a new agenda which has not been explored yet. The paper makes an input in filling the lack of research and shaping the policy of developing countries in dealing with ICT to achieve inclusive and equitable quality education. Although this research may not be generalizable, it can be considered as explanatory to other developing countries to some extent. Moreover, the study could extend the literature on ICT by examining the ICT situations in sub-Saharan Africa, and it can be used as a base for further study in ICT for post-2015 education.

\section{Literature Review}

Although highly contested and multifaceted, many studies have been done regarding ICT in developing countries. The theme for the proposed literature review is set based on the case this study focuses to analyze. Exploring the theoretical frameworks of ICT in relation with access and inclusive education as well as the opportunities and challenges of developing countries have vital importance in understanding the topic and the participants' responses regarding ICT in general and ICT in developing countries in particular.

\subsection{Access to ICT}

It is generally believed that ICT can empower education, promote change and foster the development of $21 \mathrm{st}$ century skills. However, the very limited and unequivocally compelling data makes the reality of these beliefs limited (Trucano, 2005); and the authenticity of the beliefs become even worse as it comes to developing countries. Under these conflicting situations, nation-states are now moving towards seeing ICT as central to the overall educational transformation for the post-2015 education. The Qingdao declaration asserted this by stating, "To achieve the goal of inclusive and equitable quality education and lifelong learning by 2030, ICT - including mobile learning - must be harnessed to strengthen education systems, knowledge dissemination, information access, quality and effective learning, and more efficient service provision" (UNESCO, 2015b, p. 1). This goes beyond seeing ICT as an instructional tool for complementing a teacher's existing pedagogy, rather it goes for inclusive and equitable education. 
There are certain requirements that need to be met regarding access to ICT in order for ICT to support educational change and innovation. First, there should be a wide range of ICT tools available when needed and these tools should be fit for purpose in meeting an individual needs. It is in such situation that the National Education Association (2008) stated that for ICT to become a reliable tool in education, both educators and students must have adequate access to these tools inside and outside of the school. Another issue to be dealt with is how these available ICT tools are being used for educational transformation (European Agency for Development in Special Needs Education, 2013). This mainly deals with the methods and processes used for implementing them, as well as the level of positive attitude and control that individuals have on the ICT tools. This indicates that the flowering ideas and ambitions of countries are imaginary unless they could be able to ensure that every student at any location, socio-economic status and physical condition gets connected to digital devices and makes use of them effectively. It is worth noting that such equitable access to technology is vital especially for the marginalized and disadvantaged people to bring them to the learning environment and discover their full potential.

\subsection{ICT and Inclusive Education}

According to UNESCO (2015a), inclusive education is referred both as a principle and process, arising from a clear recognition that exclusion happens not only from education, but also within education. In this sense, inclusive education seeks to address the learning needs of all children including these who are vulnerable to marginalization and exclusion. The idea lies on the principle:

Schools should accommodate all children, regardless of their physical, intellectual, social, emotional, linguistic or other impairments. They should provide for disabled and gifted children, street and working children, children from remote or nomadic populations, children from linguistic, ethnic or cultural minorities and children from other marginalized areas or groups (Rieser, 2008, p. 21).

Inclusive education requires harmonization of content, approaches, structures and strategies with a common vision to cater for all learners with respect to diversity. Therefore, in transforming the education system and responding to each learner's needs, the role of ICT is paramount. This is because the integration of ICT in education could enable different kinds of students including students with disabilities to be part of the teaching-learning process and active contributors of knowledge (Obradoviü, Bjekiü, \& Zlatiü, 2015). Our generation is a concrete example of this in which disabled people such as both deaf and blind are able to easily communicate, attend college, and contribute to their society with the help of ICT tools.

Many researchers agree that in inclusive education it is not only all aspects of ICT tools are important, but their way of application is also essential (European Agency for Development in Special Needs Education, 2013). This calls upon a strong organization and coordination of educational reforms associated with other socio-economic policies to allow full inclusion and integration of the disadvantaged students by ensuring different partnerships and alleviating restricting factors. Some of these issues include regional and/or global partnerships where developing countries adapt the technological innovations and experiences of other countries and promote socio-economic developments such as promote gender equality and alleviate poverty. When such environment is provided, ICT could be a valuable tool to improve inclusive education. In this sense, reducing the students' social inclusion could improve the students' participation and quality of life. This is because inclusion addresses the four pillar of learning: learning to know, to do, to live together and to be (UNESCO, 2015a).

\subsection{Prospects and Challenges of Developing Countries}

Different studies show that there has been increasing pressure to improve access to information and enable communication in developing countries as ICT can help countries tackle a wide range of problems (Duță \& Martínez-Rivera, 2015; Martinez-Frias, 2003; Osterwalder, 2003). This is also common in educational 
institutions where the need for ICT integration is significant even in the most challenging environments. As the world is being swiped by globalization, countries and regions are becoming closer to each other ever than before especially with the facilitation of technological and economic globalization. This interconnection of countries is also enabling for sharing and adapting the technological development as well as ideas, knowledge and practical experiences of advanced countries (King \& Palmer, 2013). The usage of ICT tools such as the Internet is one good example of this. Since the emergence of the Internet, new technologies have increased generating opportunities, projects, platforms and initiatives that have to do with learning (Duță \& Martínez-Rivera, 2015). Nowadays, the Internet has been one of the top means of communication and source of information in many developing countries especially for the younger age group.

In order to develop their ICT capacity and promote its leverage on education, developing countries are working hard by setting different policies and strategies. The technological development of the countries is also supported by the economic growth and increasing urbanization level of the countries, and with the help of other partner governments or organizations. For instance, the Global e-Schools and Communities Initiative (GeSCI) is a global technical assistance and capacity building organization that offers strategic advice to the education and training sector on the effective use of ICT for education in developing countries (Swarts \& Wachira, 2010). Many developing countries have used the assistance and expertise of such organizations and/or private consultants to develop comprehensive ICT frameworks, policies and strategies. Therefore, it could be argued that many developing countries have shown commitment to increase access to ICT and widely use them in education.

In developing countries, the progress of ICT and its integration in the teaching-learning process is not totally smooth. There are different challenges with regard to its effective use (Thi Thanh, 2008); realization of its benefits (Parliamentary Office of Science and Technology, 2006); and its gap within regions and people (Hameed, 2007).

Many developing countries have limited connectivity and network infrastructure which make access to ICT inadequate (Bhasin, 2012); and this is worse in rural areas where there is limited electricity and other services, and in students with disabilities or from low socio-economic families. This shows that there is digital gap between and within different regions and people. The Parliamentary Office of Science and Technology (2006) stated that this digital divide in developing countries is due to lack of appropriate ICT infrastructure and products; lack of technical skills to support and benefit from ICT; and cost of ICT in relation with people's standard of living.

Moreover, educators argue that in developing countries ICT is not being used for inclusion and educational equity (Lakkala \& Ilomaki, 2015; Trucano, 2005). Many places with connected digital devices have low-speed connectivity and their ICT usage is mainly confined to support existing teaching and learning practices. Besides, technology is often implemented within existing educational structures, methods and curriculum in order to facilitate the spread of advanced pedagogical practices (Lakkala \& Ilomaki, 2015). Hence, in order to benefit from ICT in ensuring inclusive and equitable quality education and creating better living conditions for the future generation, developing countries must coordinate the development of ICT infrastructure with educational policy.

\section{Methodology}

\subsection{Research Design and Participants}

The research is qualitative study. As this research analyzes how far all students will get access to ICT to strengthen education and its knowledge dissemination capacity in post-2015 education in sub-Saharan Africa, qualitative research design is used to develop explanations and understanding through the experiences and views of the participants and other related and relevant data (McNabb, 2008); and explore the implementability of the situation (Hancock, Ockleford, \& Windridge, 2009). 
The target population for the study was Africans from sub-Saharan region. Individuals with a minimum bachelor degree were used for collecting data as they could have better knowledge and understanding about ICT and ICT related issues. The total sample size of respondents was 16, representing 11 countries; and the participants were selected using purposive sampling in order to identify potential participants that represent a broader group of cases as closely as possible for the study (Teddlie \& Yu, 2007; Wiersma \& Jurs, 2004).

\subsection{Methods of Data Collection and Analysis}

Interview and document review were used to collect data for the study. Interview provides opportunity for in-depth probing, and elaboration and clarification of terms (Wiersma \& Jurs, 2004; Bryman, 2008). An interview protocol was prepared containing purpose of the study, instructions and interview questions. The participants were asked questions related to the condition of ICT and its level of integration in education as well as challenges and future trends. Participation to the study was voluntary. The purpose of the study was explained to the participants, and the response they gave is kept confidential. Pseudonyms were used to protect the identity of the participants. Related and relevant documents were also reviewed to explore the current ICT conditions and predict the possible scenario in 2030. Thematic and explanatory analysis were used to analyze the data collected through interview and document review. Then, a structural skeleton was established to provide for meaningful interpretation and discussion (McNabb, 2008). Finally, the data is rewritten with the researcher's interpretation and conclusion with a reference to the literature review and empirical studies. Although the research to some extent can be considered as explanatory, due to financial and time limitations, it was not able to include participants from the entire sub-Saharan African countries.

\section{Results and Discussions}

As in any part of the world, the economic and technological development of sub-Saharan Africa is increasing. This has also affected to the increase of educational opportunities within the countries. The question, however, comes to the level and integration of ICT in order to promote access and inclusion. In the following sections, I interweave findings from interviews and document review in themes, with the main concern to answer the research questions.

\subsection{ICT Condition in Sub-Saharan Africa}

It is understood that, as part of educational setting and infrastructure, the level and distribution of ICT are precondition for its usage in any social service including education. Besides, it should be noted that such development need to be proportional within and across regions and individuals to achieve inclusive and equitable quality education. Generally, the study found out that sub-Saharan African countries vary in their capacity of ICT where most of the countries have low ICT level. Beside, most of the countries have better distribution of ICT in the urban areas than the rural ones.

The majority participants of the study agreed that the current condition of ICT in their country is not well established, although it is progressing. Their response indicated that there is variation on the level of ICT in sub-Saharan Africa. Accordingly, the ICT condition in sub-Saharan Africa could be categorized into two levels. In many sub-Saharan Africa the level of ICT is still low. Most of the respondents shared a common view that ICT in their countries is in its infancy stage, but improving from time to time. Jemal, a respondent from Eritrea, said:

I can say the level of ICT in my country is still in its infant stage and a lot remains to go. Internet access is limited to the capital and other large cities, in some Internet cafes and offices. Considerable progress is underway especially in urban areas, as the cities have fixed telephone line and mobile telephone is almost all over the country though the Internet penetration rate is low. 
The above statement highlights the fact that sub-Saharan Africa has low ICT level especially associated with the Internet. In line with the above information, the data from the World Bank ( 2015) illustrated that in 2014 sub-Saharan Africa had 19.2 Internet users (per 100 people), in which the world's average was 40.7 (per 100 people). This figure is even lower (8.6) in least developed countries, and fragile and conflict affected situations (11.5) where many sub-Saharan African countries belong in. It is in such situation that Simon, a respondent from Liberia, stated, "Since my country recovered from 15 years of civil war that demolished its infrastructure and education system, ICT started late and is in a low level in the country". The same issue goes to other countries which had been in internal conflict or war such as Somalia, South Sudan and Eritrea. Moreover, the level of African population with access to the Internet (Internet penetration) is $28.6 \%$ compared with $46.4 \%$ of the world total; Africa has only $9.8 \%$ of the world's Internet users while the rest of the world covers $90.2 \%$ (Internet World Stats, 2015). This is very low when compared with the African population which covers $16 \%$ of the world.

Conversely, there are few countries where the level and distribution of ICT is better and developing quickly. Aaron, a respondent from Rwanda, clearly explained this:

The level of ICT in my country is very good. For example, Internet is everywhere in the country; use of computer is somehow good; the number of people with cell phone is high; Internet connectivity is above 50\%; all districts are connected to fiber optic that helps to have high speed Internet; $4 G$ is being used in the country; and ICT is mainstreamed in all sectors (Taxes, passport, ID, Bank services, registration of land, videoconferences, in health, ......). TV and Radio are digitalized; and wireless is available in some public places such as hotels, supermarkets, etc.

As the above respondent argued, these countries are committed to develop ICT as a priority for national development. Hence, they have made different initiatives including setting strong ICT infrastructure and policy to be integrated in different sectors.

All the respondents share a common view that the level of ICT in sub-Saharan Africa is worse when it comes to rural areas and slums. Maria, a respondent from Ethiopia, explained this by saying:

The distribution of ICT is not equal, of course like in any other sectors; access is higher in urban areas than rural areas. There are different reasons for this, such as poverty, electricity, infrastructure, facilities and interest in the use of ICT. Hence, many people including students in urban areas can easily buy their IT devices like computer and cell phone; and ICT use demand is high in the cities than in rural areas due to difference in economic activities. In education, the distribution of ICT also follows the same footsteps, with better facilities in urban and rich community schools.

The above excerpt indicates that the distribution of ICT is mainly associated with ICT infrastructure and socio-economic status of the people (Bhasin, 2012; Hameed, 2007). This is concurrent with the investment of governments on ICT which focuses on higher levels of education and unbalanced socio-economic condition of sub-Saharan Africa.

Consistently, the data from the document review show that the level and distribution of ICT is low and not equal between countries and regions. The number of Internet users and urban-rural condition of sub-Saharan Africa verify the above statement of the respondent. In 2014, the urban population in sub-Saharan Africa accounted for $37 \%$ of the total population, in which the world's average was 53\% (World Bank, 2015). It could be understood that most of the $67 \%$ rural population might not get basic ICT infrastructure and tools to get access to ICT. 


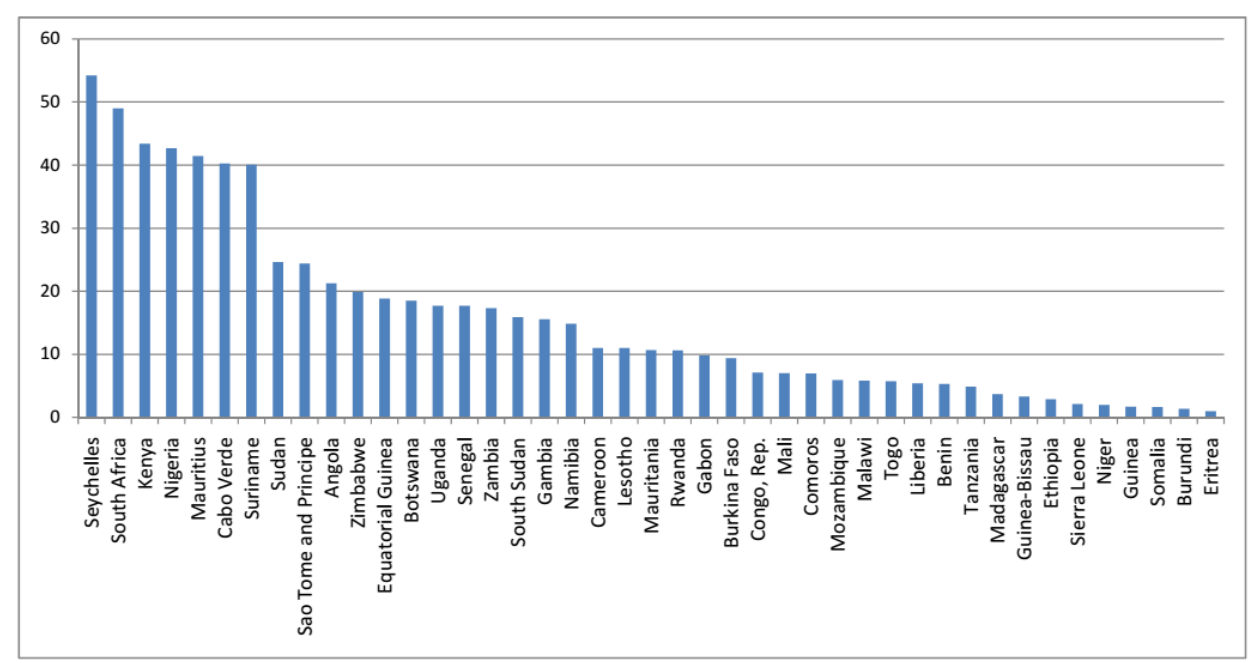

Figure 1. Number of Internet users per hundred inhabitants in 2014, by country (World Bank data, 2015)

The above figure shows that the distribution of Internet users (per 100 people) in sub-Saharan Africa varies among the different countries. Only seven countries rose above 40 Internet users (per 100 people), with Seychelles being the highest having 54.3 Internet users (per 100 people). However, all the other countries stretch between 25 and 1 Internet users (per 100 people). This figure therefore indicates that in sub-Saharan Africa few number of individuals use the Internet within a year, regardless of their location and devices such as computer, mobile phone, and others.

Finally, it could be noted that all the above information reveals that sub-Saharan Africa has low ICT coverage with uneven distribution across countries, regions and levels of population.

\subsection{ICT Integration in Education}

According to UNESCO Institute for Statistics (2015), in sub-Saharan Africa there is lack of systematic data collections which has been a significant obstacle in measuring ICT in education. However, considering the level and distribution of ICT, it could be argued that the level of ICT integration in education could not be strong and varies with the variation and distribution of ICT infrastructure. That could be the reason that most of the respondents first highlighted the condition of ICT at national level to address its integration in education. Then, they discussed about the level of ICT infrastructure and other educational settings such as curriculum, pedagogy, level of teachers, etc. within schools. Explaining this issue, Juliet, a respondent from Ghana, said, "I think the ICT integration in my country is not equal in the sense that parts of the country get the chance to enjoy while others do not, causing educational imbalance".

Most of the respondents agree with the above excerpt focusing on three points. In sub-Saharan Africa, ICT integration in education is low (Bhasin, 2012) and it is much lower in some regions especially rural schools (Hameed, 2007); It is mainly meant to support the teaching-learning activities by searching information or teaching materials (Lakkala \& Ilomaki, 2015); and ICT is creating educational divide within and across countries (Parliamentary Office of Science and Technology, 2006). Lippi, a respondent from Tanzania, stated:

The level of ICT integration in education is low in my country, which affects that most of the students cannot compete with those from developed countries as we are in globalized world. This is because ICT integration has influence on sharing of ideas, access to materials, knowledge accumulation, and so on.

Many other respondents also asserted that both teachers and students have inadequate access to ICT in schools, and this hinders interaction, flexibility and inclusion of students in the teaching-learning process. 
Samuel, a respondent from Eritrea, reiterated this by stating:

I can say that integration of ICT in education is at its early stage in Eritrea, particularly ICT tools associated with the Internet; and this has greatly affected the education system of the country because it is not coping with the modern world. In this information age, the way of learning is totally changing from day to day with the change of technology. Students in developed countries are digging out infinite information with a click of mouse with all possibilities and flexibilities. However, many students from my country lack such golden opportunities miserably and their creativity and flexibilities depend on teachers which follow the traditional way of teaching-learning process.

The argument of these participants centers on the points that sub-Saharan Africa lacks well integrated ICT system in education to enable student-centered and collaborative learning effectively and efficiently. All these reflect the idea of many educators that state in developing countries ICT is used to facilitate the teaching-learning, but not to promote inclusion and educational equity (Lakkala \& Ilomaki, 2015; Trucano, 2005). Besides, the more students are not equipped with ICT skills, the more it becomes hard as they advance in their academic journey to access useful information and cope with global changes and market demand.

The data from different documents reveal that sub-Saharan African countries have different level of ICT commitment and integration. In order to improve their conditions, a number of sub-Saharan African countries are working to strengthen the integration of ICT in education simultaneously with their development of ICT and its infrastructure. In some countries, such as Rwanda, Uganda, Namibia, Nigeria, Kenya and Zimbabwe, ICT is organized at ministry level. This shows not only the commitment of the countries for development of ICT, but also for the development and coordination of their national policies and programs in connection with ICT policies and programs. Concerning the education sector, many countries have set a policy addressing ICT in education. However, in some countries, like Djibouti and Togo, ICT in education policy particularly covers certain education levels, most commonly upper secondary education; whereas Cameroon, Comoros, Congo, Guinea, Lesotho and Madagascar lack an active ICT policy or plan (UNESCO Institute for Statistics, 2015). Such lack of specific policy guiding the use of ICT in education usually leads for a fragmented development and application of ICT within educational institutions. The entire respondents and statistical data from many countries also reveal that the integration of ICT in education is better in secondary schools than primary ones.

Generally, although the level of ICT commitment from government does not necessary affect the ICT level and integration in education in all countries at this time, it might make an impact sooner or later. This is because clear policies and strong commitment and organization could lead countries to have fast growth of ICT and its application in different sectors including education.

\subsection{Challenges of Sub-Saharan Africa}

The respondents indicated that there are various reasons for the low development of ICT and its integration in education in sub-Saharan Africa. Generally, these challenges can be categorized into the following themes:

Shortage of Electricity - Africa is rich in fossil fuels and renewable resources. However, many sub-Saharan African countries are facing electricity crisis in which $70 \%$ of the population are without electricity (United States Department of Commerce, 2014). In 2013, 59\% of the urban inhabitants of sub-Saharan Africa had access to electricity, whereas the number is much lower (17\%) in rural areas (World Energy Outlook, 2015). Besides, as it is indicated in the following figure (Figure 2), there is variation of access to electricity among the countries and between cities and villages. Considering the fact that most of the inhabitants of sub-Saharan Africa live in rural areas, the impact could be very large. 


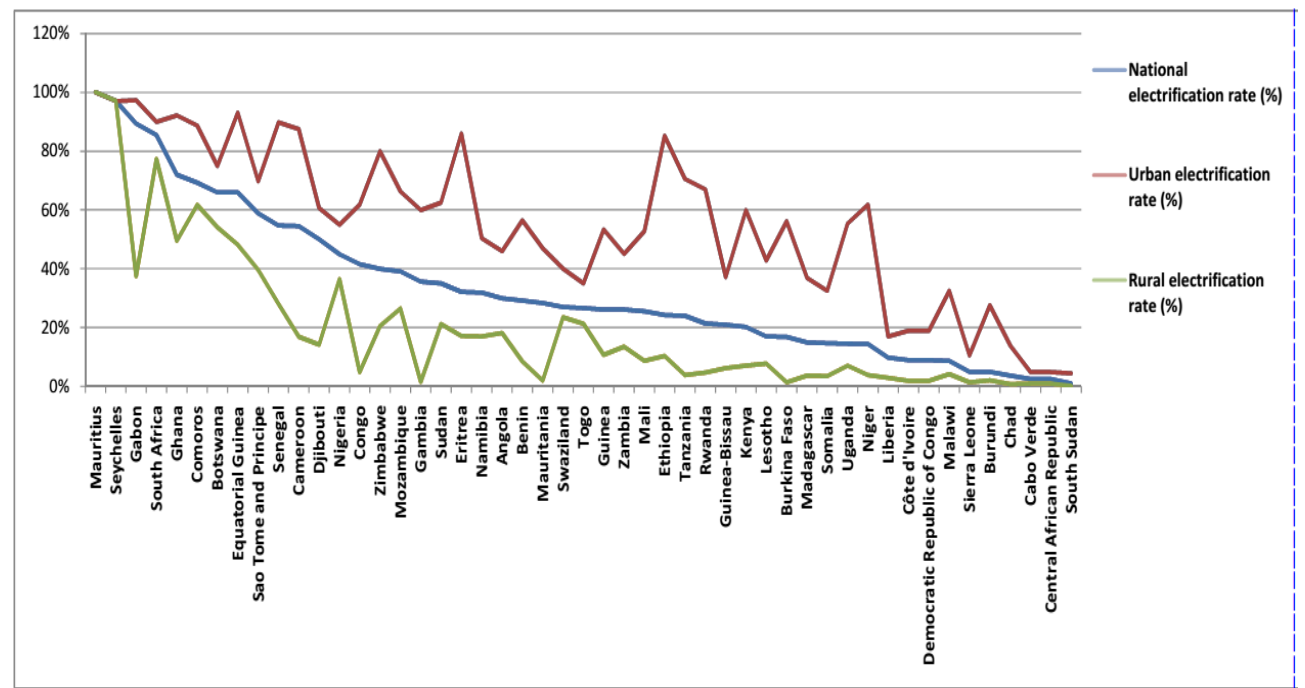

Figure 2. Electricity access in 2013, by country (World Energy Outlook, 2015)

Moreover, the energy sector of Africa is characterized by low access, insufficient capacity, poor reliability and high costs (World Bank, 2013). Hence, this is impeding the socio-economic development of the countries; and the obstacle becomes severe as it comes to ICT since modern technology needs power supply for effective and efficient use.

Inadequate ICT Infrastructure and Facilities - Many sub-Saharan African countries are among the least developed countries of the world. They lack ICT equipment and have inadequate budget to purchase new ones. Many students and teachers do not own their ICT tools such as computer due to economic, technical and other reasons. In addition, many sub-Saharan African countries officially introduced ICT into education in the $21 \mathrm{st}$ century, and some of the countries do not have specific policy guiding the use of ICT in education yet. Besides, there are no enough skilled human resources to maintain and manage the ICT and facilitate its integration in education. It is in such situation that researchers argued for significant consideration on the way how ICT should be applied as much as on their access (European Agency for Development in Special Needs Education, 2013; Thi Thanh, 2008)

Lack of Commitment from Governments - Not all sub-Saharan African governments show strong commitment to prioritize ICT. This could be connected to many reasons including other priorities such as poverty, food security, and water and sanitation facilities. Hence, many governments have not given the required attention in terms of allocating adequate budget for procuring ICT facilities and developing strategies to integrate educational programs with ICT. Furthermore, many governments complain that some individuals use ICT tools especially the Internet for political instability and terrorism. Therefore, they either do not make every effort to develop it or strictly control its usage.

Lack of Strong Private Sector - Most of African countries had been under Western colonialism up to the 1960s. At independence, these countries received an economic structure that was not geared toward transformation and value addition, but rather raw materials extraction and export. Given such conditions, many African countries lack competitive domestic private sectors such as strong information technology companies to cooperate with the educational institutions for supply of ICT tools and experts as well as facilitation of ICT integration in education.

\subsection{Future Trends of ICT in Sub-Saharan Africa}

The respondents viewed different anticipation with regard to access to connected digital devices and provision of relevant and responsive digital learning environment by 2030. Considering the current condition of ICT and its integration in education, majority of the respondents shared that by 2030 it will be difficult for 
sub-Saharan Africa to ensure all students to get access to ICT tools connected with the Internet and be fully integrated in education to enable inclusive and equitable education. Steven, a respondent from Tanzania, elucidated this:

I don't see the possibility of having all students accessing digital devices by 2030. Even the Education for All which has existed for a decade and half has not reached all students to the moment although the majorities are schooling. Similarly, providing digital devices for all students by 2030 may be a viable target but practically impossible given the level of economy we have. The government priority has been to try to move the country from Least developed to the Middle income by 2025. And ensuring digital connectivity for more than 15 million learners (from pre-primary to tertiary) requires a huge investment. I am not sure if the education sector investment will come as a top priority among the other sectors investments.

Other respondents further supplemented that the distribution of ICT makes it much harder for some groups such as disabled students and these from low socio-economic status and rural areas.

On the other hand, few respondents argued that if sub-Saharan Africa could overcome the challenges such as electricity and government's commitment to ICT, there is a possibility that every student could get access. Lulu, a respondent from Zambia, clearly explained this:

Driven by rapid technological changes and innovations, I believe that ICT equipment will be cheaper and easily accessible. Therefore, if governments could make cohesive policy of ICT towards education and fully use the overwhelming emergence of ICT, it is possible that students will fully get the opportunity for relevant and responsive digital learning environment by 2030.

The respondents with similar perception also emphasized that the economic progress will enable many students to have their own ICT tools within the coming decade. This could then support governments to focus on the disadvantaged groups.

Looking at the progress and trends of sub-Saharan Africa, the data concur with the idea of the participants who claim that by 2030 it will be difficult for sub-Saharan Africa to ensure all students to get access to ICT and fully apply them in schools.

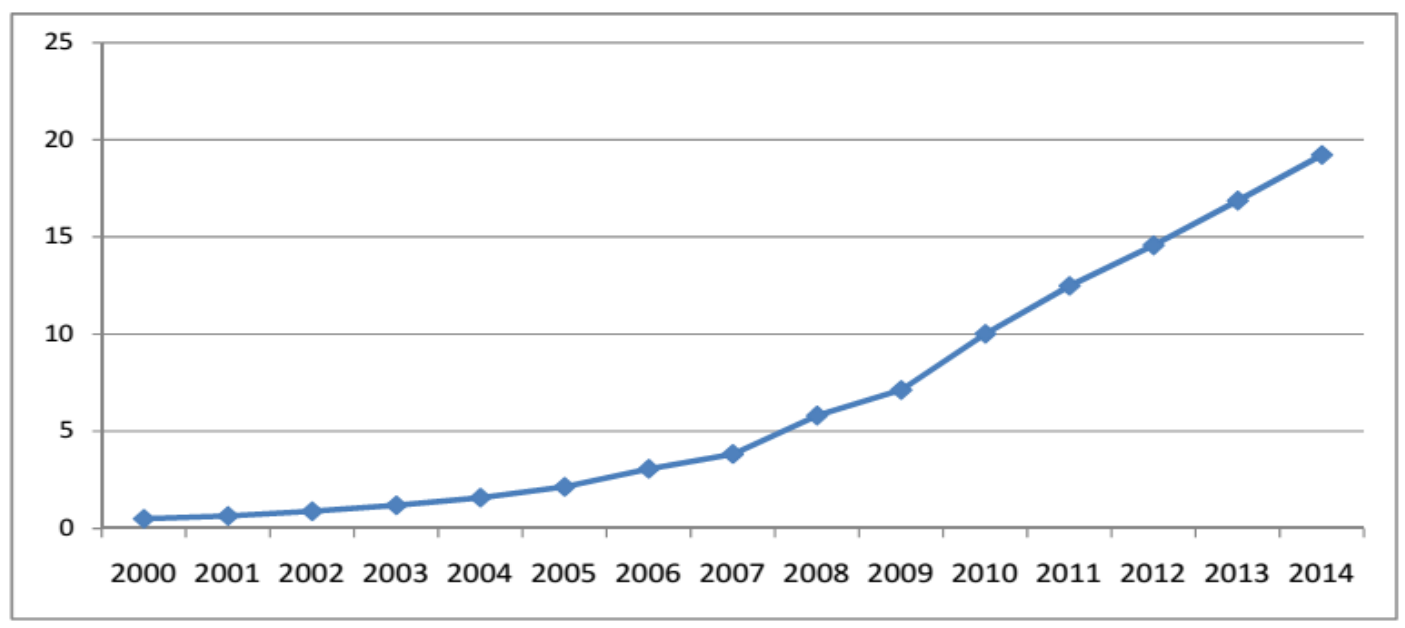

Figure 3. Number of Internet users per hundred inhabitants in sub-Saharan Africa, by year (2000 -2014)

(World Bank data, 2015)

As indicated in the above figure, the number of Internet users per hundred inhabitants showed a very sharp increase from 2007 onwards. However, within seven years, it only added 15 users (per 100) to reach 20 users (per 100) by 2014. This shows that sub-Saharan Africa needs to step up its efforts drastically; unless the entire 
inhabitants could not use Internet by 2030 with such situation.

The following graph depicts the number of people who got access to electricity in the sub-Saharan Africa in the year 2012, and predicts the situation for the coming quarter a century.

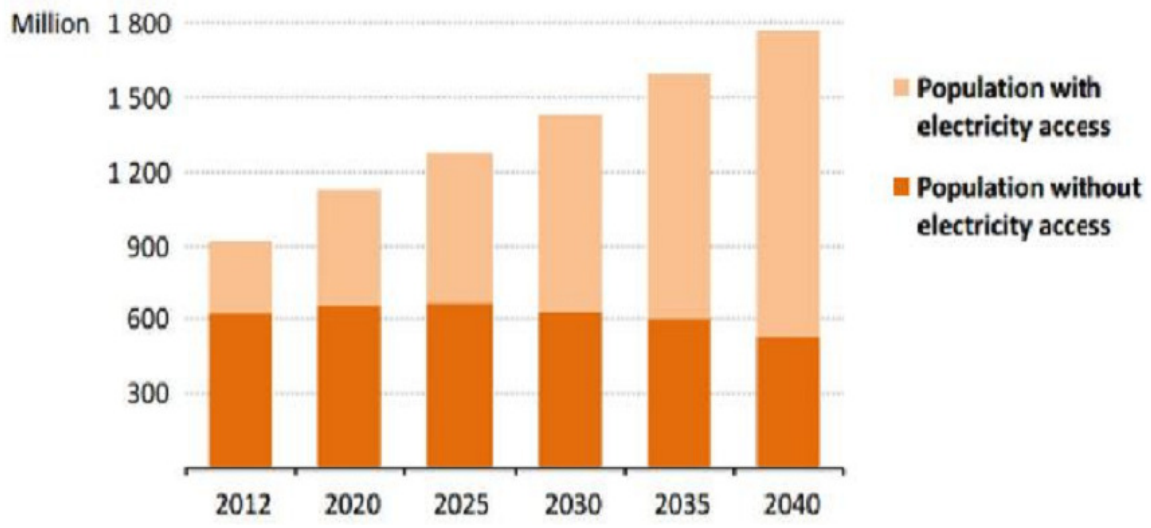

Figure 4. Access to electricity in sub-Saharan Africa (Crisp, 2014)

Accordingly, by 2030 about 600 million inhabitants will still remain without electricity, and this lack of power will not be totally eradicated even by 2040, especially in the rural areas. This makes for sub-Saharan Africa difficult to ensure full access to connected digital devices and its integration in education by 2030.

\section{Conclusion and Implication}

Neither the MDGs nor EFA provided concrete objectives or goals concerning the role and integration of ICT in education. This might have affected the development and priority of ICT in education by many governments. The study showed that the level and distribution of ICT is at its infant stage in most part of sub-Saharan Africa, and this has affected the integration of ICT in education.

Despite many challenges, currently the situation is changing in which many countries are focusing on ICT as a main tool of progress, and effective and efficient delivery of services in many sectors including education. Nonetheless, access to ICT and its integration in education is different between countries and within different regions and socio-economic status of the people. Rural areas and people with low socio-economic status have low access than urban areas and the rich. Moreover, schools use ICT to supplement the teaching-learning by finding some materials mainly from the teacher's side.

The study found out that there is a mixed perception of people whether sub-Saharan Africa could ensure all students to have access to connected digital devices and relevant and responsive digital learning environment by 2030. The situation seems difficult for many countries with the current level of progress, and many of the challenges which are critical for ICT development such as electricity will not fully be achieved by 2030 . Nevertheless, some data indicate that there might be a room for few countries such as Seychelles and Mauritius that have good infrastructure and are working diligently.

The implication of the study for the policy makers is that setting similar goals for countries which have different socio-economic and political situations is not fully realistic. The level of ICT in education in sub-Saharan Africa is much lower than the developed world. Besides, there are various issues such as food and other basic social services that the least developed countries have not yet fulfilled. Hence, the trend seems to go without much change (except in few countries) until 2030, the time when both the Incheon and Qingdao declarations expire; sub-Saharan Africa could not achieve inclusive and equitable quality education and lifelong learning for all by 2030 .

The study implies that the level of ICT in education could determine the educational gap between students 
and regions. The technologically advanced countries use well established and timely ICT system to teach their students. In such situation, teachers are able to be flexible in their educational delivery, and students can develop fundamental knowledge and competencies. Whereas the low level and slow progress of ICT in sub-Saharan Africa could not enable educational institutions to enjoy the benefits that the teachers and students from the developed world are getting. Therefore, this situation could increase the educational gap between developing and the developed world.

\section{References}

Bhasin, B. (2012). Integration of information and communication technologies in enhancing teaching and learning. Contemporary Educational Technology, 3(2), 130-140.

Bryman, A. (2008). Social research methods (3rd ed.). New York: Oxford University Press.

Crisp, J. (2014). IEA: Sub-Saharan Africa will produce more gas than Russia. Retrieved from http://www.euractiv.com/sections/energy/iea-sub-saharan-africa-will-produce-more-gas-russia-309599

Dorsi, D. (2015). Applying right to education indicators to the post-2015 education agenda. London: Right to Education Project.

Duță, N., \& Martínez-Rivera, O. (2015). Between theory and practice: the importance of ICT in higher education as a tool for collaborative learning. Procedia - Social and Behavioral Sciences, 180, 1466-1473. http://dx.doi.org/10.1016/j.sbspro.2015.02.294

European Agency for Development in Special Needs Education. (2013). Information and communication technology for inclusion: Research literature review. Odense: European Agency for Development in Special Needs Education.

Hameed, T. (2007). ICT as an enabler of socio-economic development. Retrieved from http://www.itu.int/osg/spu/digitalbridges/materials/hameed-paper.pdf

Hancock, B., Ockleford, E., \& Windridge, K. (2009). An introduction to qualitative research. Nottingham and Sheffield: National Institute for Health Research.

Internet World Stats. (2015). Internet usage statistics for Africa: Africa Internet usage and 2015 population stats. Retrieved from http://www.Internetworldstats.com/stats1.htm

King, K., \& Palmer, R. (2013). Post-2015 agendas: Northern tsunami, southern ripple? The case of education and skills. International Journal of Educational Development, 33, 409-425. http://dx.doi.org/10.1016/j.ijedudev.2013.06.001

Lakkala, M., \& Ilomaki, L. (2015). A case study of developing ICT-supported pedagogy through a collegial practice transfer process. Computers \& Education, 90, 1-12. http://dx.doi.org/10.1016/j.compedu.2015.09.001

Marginson, S. (2010). Higher education in the global knowledge economy. Procedia Social and Behavioral Sciences, 2(5), 6962-6980. http://dx.doi.org/10.1016/j.sbspro.2010.05.049

Martinez-Frias, J. (2003). The importance of ICTs for developing countries. Interdisciplinary Science Reviews, 28(1). http://dx.doi.org/10.1179/030801803225010304

McNabb, D. E. (2008). Research methods in public administration and nonprofit management: Quantitative and qualitative approaches (2nd ed.). New Delhi: PHI Learning Private Limited.

National Education Association. (2008). Access, adequacy, and equity in education technology: Results of a survey of America's teachers and support professionals on technology in public schools and classrooms. Retrieved from http://www.nea.org

Negroponte, N. (1998). The third shall be first: The net leverages latecomers in the developing world. Retrieved from http://web.media.mit.edu/ nicholas/Wired/

Obradoviü, S., Bjekiü, D., \& Zlatiü, L. (2015). Creative teaching with ICT support for students with specific learning disabilities. Procedia - Social and Behavioral Sciences, 203, 291-296. http://dx.doi.org/10.1016/j.sbspro.2015.08.297

Osterwalder, A. (2003). ICT in developing countries: A cross-sectoral snapshot. Retrieved from http://www.hec.unil.ch/aosterwa/Documents/InternetInEmergingMarkets/Publications/ISGLOB03.pdf 
Tsegay, S. M.

Parliamentary Office of Science and Technology. (March 2006). ICT in developing countries. POSTnotes, 26, 1-4. Retrieved from http://researchbriefings.parliament.uk/ResearchBriefing/Summary/POST-PN-261

Rieser, R. (2008). Implementing inclusive education: A Commonwealth guide to implementing Article 24 of the UN Convention on the rights of people with disabilities. London: Commonwealth Secretariat.

Swarts, P., \& Wachira, E. M. (2010). Tanzania: ICT in education-situational analysis. Dar es Salaam: The Global e-Schools and Communities Initiative.

Teddlie, C., \& Yu, F. (2007). Mixed methods sampling: A typology with examples. Journal of Mixed Methods Research, 1(1), 77-100. http://dx.doi.org/10.1177/2345678906292430

Thi Thanh, N. H. (2008). Strengthening ICT leadership in developing countries. The Electronic Journal on Information Systems in Developing Countries, 34(4), 1-13.

Trucano, M. (2005). Knowledge maps: ICTs in education. Retrieved from http://www.infodev.org/education

UNESCO Institute for Statistics. (2015). Information and Communication Technology (ICT) in education in sub-Saharan Africa: A comparative analysis of basic e-readiness in schools (Information Paper NO. 25). Montreal: UNESCO-UIS.

UNESCO. (2015a). Inclusive education. Retrieved from http://en.unesco.org/world-education-forum-2015/5-key-themes/inclusive-education

UNESCO. (2015b). Qingdao declaration: International conference on ICT and post-2015 education. Qingdao City: UNESCO.

United Nations Development Programme. (2010). Beyond the midpoint: Achieving the millennium development goals. New York: USA.

United Nations. (2015). Millennium development goals report 2015. New York: USA.

United States Department of Commerce. (2014). Blog category: Power Africa. Retrieved from http://2010-2014.commerce.gov/blog/category/2476

Wiersma, W., \& Jurs, S. G. (2004). Research methods in education: An introduction (8th ed.). China: Pearson Education Asia Ltd and China Light Industry Press.

World Bank. (2013). Fact sheet: The World Bank and energy in Africa. Retrieved from http://www.worldbank.org/

World Bank. (2015). World Bank data. Retrieved from http://data.worldbank.org/

World Energy Outlook. (2015). Electricity access database. Retrieved from http://www.worldenergyoutlook.org 